\title{
Abiotic parameters and planktonic community of an earthen fish pond with continuous water flow
}

\author{
Parâmetros abióticos e comunidade planctônica em viveiro de piscicultura com \\ fluxo contínuo de água
}

\section{Lúcia Helena Sipaúba-Tavares $^{1 *}$ (D), Rodrigo Ney Millan² (D), Érica Camargo Oliveira Capitano and Bruno Scardoelli-Truzzi ${ }^{1}$}

${ }^{1}$ Centro de Aquicultura, Universidade Estadual Paulista - UNESP, Via de Acesso Prof. Paulo Donato Castellane, s/n, Bairro Rural, CEP 14884-900, Jaboticabal, SP, Brasil

${ }^{2}$ Departamento de Ciências Exatas e da Terra, Universidade do Estado de Minas Gerais - UEMG, Avenida Prof. Mario Palmério, 1001, Bloco B, CEP 38200-000, Frutal, MG, Brasil

*e-mail: lucia.sipauba@unesp.br

Cite as: Sipaúba-Tavares, L.H. et al. Abiotic parameters and planktonic community of an earthen fish pond with continuous water flow. Acta Limnologica Brasiliensia, 2019, vol. 31, e13.

Abstract: Aim: Limnological conditions, phytoplankton and zooplankton communities in a fishpond highly affected by management during the dry and rainy seasons are investigated. Methods: Water samples were analyzed for physicochemical parameters; soil samples were analyzed for macro- and micro-nutrients, phytoplankton and zooplankton communities, at four sites, during eight months in the rainy and dry seasons. Distance-based linear model (DISTLM) was applied with Akaike Information Criterion (AIC), where the influence of environmental variables in the variation of phytoplankton and zooplankton composition could be assessed and the best model could be selected. Results: The multiparameter test revealed that variables $\mathrm{pH}$, TSS and TP better explain the composition of the biotic community $(\mathrm{AICc}=45.6 ; \mathrm{R} 2=0.80)$. Chlorophyceae was the dominant group with 32 taxa, or rather, $75-85 \%$ of total phytoplankton, with high density at 2,365-4,180 ind.L $\mathrm{L}^{-1}$ during the sampling period. Rotifera was the most abundant group in the zooplankton community during the two seasons, except at IW2 during the dry season, when Copepoda had a higher density, namely, $52 \%$ of total zooplankton community at this site. Conclusions: The contribution of allochthonous material to the fishpond during the two seasons mainly consists of macro- and micro-nutrients and thermotolerant coliforms that influenced the plankton community and enhanced high Cyanobacteria density in the rainy season. Plankton community in the studied pond was characteristic of small water bodies. Management protocol in places with continuous water flow according to the region may be an important tool to optimize and to avoid risks in fish production.

Keywords: rainy and dry seasons; aquaculture; management; phytoplankton and zooplankton.

Resumo: Objetivo: O objetivo deste estudo foi investigar as condiçóes limnológicas, fitoplâncton e zooplâncton em um viveiro fortemente afetado pelo manejo em duas estaçóes do ano, seca e chuva. Métodos: Foram analisados os parâmetros físicos e químicos da água, os macro e micronutrientes do sedimento, fitoplâncton e zooplâncton, em quatro diferentes pontos de coleta durante oito meses, nas estaçóes chuva e seca. Para avaliar a influência das variáveis ambientais na variação da composição do fitoplâncton e zooplâncton e selecionar o melhor modelo explicativo foi aplicado Distance-Based Linear Model (DISTLM) utilizando o critério de informação Akaike (AIC). Resultados: De acordo com o teste multiparamétrico aplicado, as variáveis $\mathrm{pH}$, STS e fósforo total são as que melhor explicam 
a composição da comunidade biótica ( $\mathrm{AICc}=45,6$ e R2 $=0,80$ ). Em relação ao fitoplâncton, as Chlorophyceae apresentaram 32 taxa correspondendo a um percentual de $75-85 \%$ do fitoplâncton total, com elevada densidade alcançando 2.365-4.180 ind. $\mathrm{L}^{-1}$ durante o período de amostragem. $\mathrm{Na}$ comunidade zooplanctônica o grupo mais abundante em ambas as estaçóes foi Rotifera, exceto em IW2 durante a estaçáo seca, quando a densidade de Copepoda foi mais elevada correspondendo aos $52 \%$ da comunidade zooplanctônica local. Conclusáo: A contribuiçấo do material alóctone para o viveiro de peixes durante as duas estaçóes consiste principalmente de macro e micro nutrientes e coliformes termotolerantes que influenciaram a comunidade planctônica promovendo elevada densidade de Cyanobacteria na estaçáo chuvosa. A comunidade planctônica do viveiro de piscicultura foi característica de ambientes rasos e pequenos. Um protocolo de manejo em piscicultura com fluxo contínuo de água deve ser adotado, de acordo com as condiçóes de cada região, como ferramenta para se evitar riscos na produçấo de peixes.

Palavras-chave: estação de chuva e seca; aquicultura; manejo; ftoplâncton e zooplâncton.

\section{Introduction}

The management of small artificial water bodies is affected by the physicochemical parameters of water and the plankton community. Small fishponds are usually man-made shallow water bodies constructed for a variety of reasons, mainly aquaculture. They are a great contribution to the regional freshwater biodiversity. It is very important to monitor the physical and chemical parameters in small artificial ponds to understand their influences on the distribution of aquatic organisms. In fact, several characteristics of fish ponds, which may be spatial, temporal, physical, chemical and biological, impact plankton community (Das et al., 2018).

Fish ponds are highly affected by weather and several anthropogenic factors, such as high fish density, fertilization, additional feeding of fish with their high nutrient sources. Every fishpond has a rich nutrient pool on its bottom sediments (Kopp et al., 2016).

Phytoplankton community is affected by the trophic state of water and by changes in the taxonomic composition of plankton following increases in nutrient loading and changes in nutrient absorption differences by different species (Fonseca $\&$ Bicudo, 2010). Although the zooplankton community (Rotifera and Copepoda) are the most abundant taxa in eutrophic fish ponds, it is difficult to pinpoint a single abiotic factor that controls the biological processes occurring in the fish pond (Ikpi et al., 2013).

Phosphorus is one of the key nutrients that cause algal blooms and problems in the quality of water bodies. Although sediments function as a sink where phosphorus particles, settling on the bottom, submerge and are stored, the mineralization of organic matter and reduction of iron reactivate the phosphorus. Other elements in the sediment, such as $\mathrm{Cu}, \mathrm{Zn}, \mathrm{Mg}$ and $\mathrm{Fe}$, are essential micronutrients used by the organisms (Shao et al., 2014).
Fish ponds with continuous water flow (that is, water distributed from one fish pond to another) are influenced by allochthonous loads that may cause an ecological disturbance by altering water biotic and abiotic conditions. They exert a strong influence on the plankton community (Sipaúba-Tavares et al., 2010). Eventually, the water characteristics of one fish pond may affect the following one, increasing the load of nutrients and propagating aquatic plants. The above negative effect occurred twice in the fish pond under analysis, namely, in the summer of 2009 (a monospecies invasion) and in the winter of 2010 (a multispecies invasion), with consequences on the management of fish ponds of the aquaculture farm. High expenditure was required to neutralize damages in fish production and to remove the aquatic plants (Sipaúba-Tavares et al., 2017). Further, the fish pond is important in the aquaculture farm since the water is reused by other fishponds or removed to the shrimp farming sector.

Although various studies have indicated the influence of different abiotic factors on the plankton community (Kopp et al., 2016; Arruda et al., 2017; Zebek \& Szymanska, 2017; Balkic et al., 2018), no research has been done on a fish pond invaded by macrophytes. The fish pond had to be kept at low fish density and without feed during one year. The plankton community structure and several abiotic parameters are assessed to understand the real conditions of the fish pond during the rainy and dry seasons. However, changes in the intensity of rainfall affect abiotic parameters that, in turn, also affect the biomass of aquatic organisms. Current study investigates the limnological conditions and plankton community in fish pond highly affected by management during the rainy and dry seasons. The hypotheses are (1) a span of one year without feed management enhances the fish pond limnological conditions; (2) environmental variables and the plankton community are affected 
by continuous water flow; (3) the limnological conditions of the fish pond allows the water can be used as water supply for other sectors of the fish farm.

\section{Materials and Methods}

\subsection{Study area}

Current study was performed in a fish pond on an aquaculture farm $\left(21^{\circ} 15^{\prime} 19^{\prime \prime} S\right.$; $\left.48^{\circ} 19^{\prime} 21^{\prime \prime} \mathrm{W}\right)$. The fish pond measured $4,268 \mathrm{~m}^{2}$ and had a maximum depth of $1.3 \mathrm{~m}$, with continuous water flow and water renewal (calculated by discharge volume) equivalent to $5 \%$ of total volume per day. The fish pond is the fourth in a sequential series of six similar size fish ponds (area between 2,036 $\mathrm{m}^{2}$ and $8,067 \mathrm{~m}^{2}$ ), each directly and/or indirectly receives water from the previous one through an underground pipe grid (Figure 1). The fish pond has two water inlets at its northern end: it receives water from the previous fish ponds in sequence and from a total of forty-nine small fish ponds, each featuring an area between $45 \mathrm{~m}^{2}$ and $400 \mathrm{~m}^{2}$, and from the frog culture sector. The water outlet lies at the south end of the fish pond. The fish pond is focused because it supplies water to other sectors of the fish farm and was twice invaded by macrophytes. One invasion occurred by a monospecific species (Salvinia auriculata) and the second invasion occurred with multiple macrophyte species (S. auriculata,
Lemna minor, Eichhornia crassipes, Panicum repens, Polygonum capitatum, Typha domingensis and Cyperus rotundus) (Sipaúba-Tavares et al., 2017). Posterior to the second invasion, the fish pond remained for one year with only a minimum amount of fish approximately 400 specimens of Ctenopharyngodon idella, without any food addition.

\subsection{Sampling locations}

Current study was performed one year after the second macrophyte invasion, during the rainy summer (January-April, 2012) and dry winter (May-August, 2012) seasons. Surface water, plankton and sediment samples were collected monthly at four sampling sites: two near the water inlets (IW1 and IW2), the third at a site close to the center of the fish pond, at its deepest point (FP) and the fourth near the water outlet (WO) (Figure 1).

\subsection{Water samples and climatic factors}

Water samples from a depth of $10 \mathrm{~cm}$ were collected at 8:00 with a1-L van Dorn bottle and transported to the laboratory in refrigerated polyethylene bottles. Conductivity (Cond), temperature, dissolved oxygen (DO) and $\mathrm{pH}$ were measured in situ with a Horiba U-10 multi-probe. Total phosphorus (TP) and total inorganic nitrogen (TIN) were quantified by spectrophotometer, following Golterman et al. (1978) and

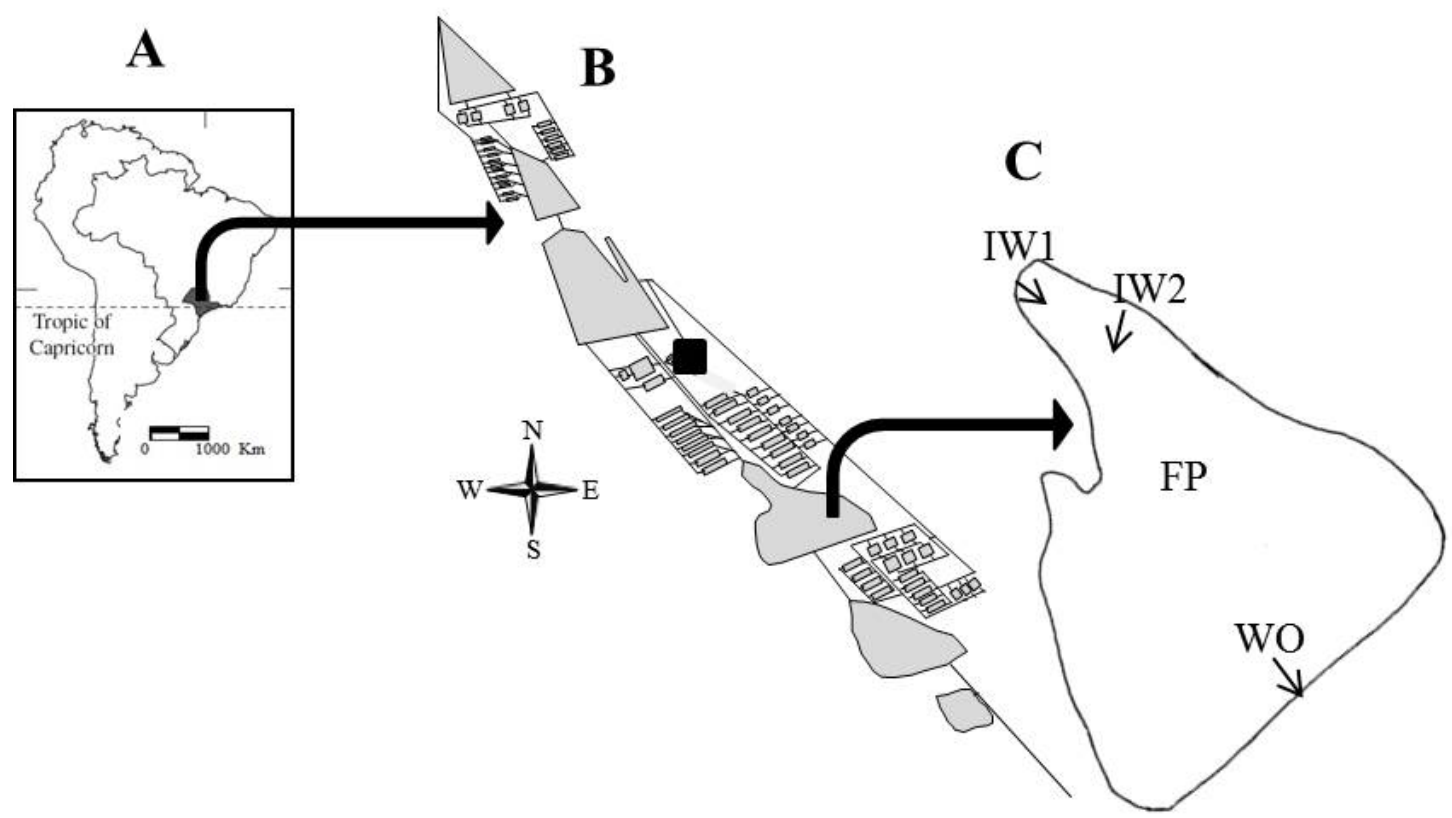

Figure 1. Diagram of the fish pond: Inset A: shaded area indicates southeastern Brazil (State of São Paulo). Inset B: aquaculture farm of the Universidade Estadual Paulista. Inset C: fish pond studied with the sampling sites: IW1 and IW2 = water inlets; FP = deep water site; WO = water outlet and $\boldsymbol{\square}=$ frog culture sector. 
Koroleff (1976). Total suspended solids (TSS), total dissolved solids (TDS) and 5-day biochemical oxygen demand $\left(\mathrm{BOD}_{5}\right)$ were determined according to Boyd \& Tucker (1992). Water samples for microbiological analysis using the multiple-tube method, were collected in 500-mL flasks and taken to the laboratory in an isothermal container. The material for thermotolerant coliforms (TC) analysis was sterilized prior to use (APHA, 1995). Data on monthly precipitation and air temperature were supplied by the Agricultural Climatology Station of the "Universidade Estadual Paulista" (São Paulo, Brazil).

\subsection{Sediment}

Sediment samples were collected at the same sites as those for water samples. Vertically mixed sediment samples were retrieved with a $4 \mathrm{~cm}$ diameter PVC core up to approximately $10 \mathrm{~cm}$ deep. Sediments were air dried in the laboratory, gently disaggregated and dried in a convection oven at $70{ }^{\circ} \mathrm{C}$ until completely dry. Further, $\mathrm{pH}$, organic matter $(\mathrm{OM}), \mathrm{Cu}, \mathrm{Mg}, \mathrm{Mn}, \mathrm{P}, \mathrm{K}$ and $\mathrm{Ca}$ were determined following Raij et al. (2001).

\subsection{Plankton}

Zooplankton was sampled by filtering $10 \mathrm{~L}$ of water through a $58 \mu \mathrm{m}$ pore-size-net and concentrated to $50 \mathrm{ml}$. Formalin was added to reach a $4 \%$ final concentration. Copepoda and Cladocera were identified in a reticulated acrylic chamber under a stereomicroscope (40x). Rotifera was identified and counted in a Sedgewick-Rafter chamber under a Leitz microscope (100x). Phytoplankton samples were collected with polyethylene bottles and preserved with Lugol solution 1\%. Phytoplankton abundance was estimated by counting the cells using Utermöhl sedimentation chambers, following Lund et al. (1958). Phytoplankton counting was carried out in an inverted microscope Axiovert 40 CFL (Carl Zeiss).

\subsection{Statistical Analysis}

All data were calculated by one-way analysis of variance (ANOVA) and post-hoc. Tukey's HSD multiple comparison test with Statistica 8.0 was employed to compare sites (IW1, IW2, FP and WO) and seasons (rainy and dry) at $\mathrm{p}<0.05$ significance level. Analyses of dominance and abundance of species were performed for the plankton community. Species were considered dominant when density was higher than $50 \%$ of the total number of specimens in the sample; they were abundant when the number of specimens was higher than the mean density of all occurring species (Lobo \& Leighton, 1986). Plankton community diversity was calculated with Shannon-Wiener $\left(\mathrm{H}^{\prime}\right)$ index; richness $(\mathrm{S})$ was calculated as the total number of species present; evenness or equitability (E) was determined as $\mathrm{H} / \mathrm{H} \max$, where $\mathrm{H}$ is the Shannon-Wiener index and $\mathrm{H} \max =\ln S$ (Pielou, 1975). Distance-based linear model (DISTLM) was applied with Akaike Information Criterion (AIC) (Anderson et al., 2008), where the influence of environmental variables in the variation of planktonic community composition could be assessed and the best model could be selected. AIC was adopted for cases in which the number of samples is small when compared to the predicted variables (Burnham \& Anderson, 2002). Procedure BEST was employed to calculate AIC for all possible models which are identified with the lowest AIC rate $(\operatorname{AICc}(\min ))$. Environmental data were transformed into $(\log (\mathrm{x}+1))$ and biotic data were transformed into square root and then standardized (Clarke \& Warwick, 1994). Further, 999 mutations were performed for analyses. Bray-Curtis similarity index was employed for abundance data. Analyses were performed with PRIMER v.6+PERMANOVA (Anderson et al., 2008).

\section{Results}

During the rainy season daily averages were $24 \pm 1{ }^{\circ} \mathrm{C}$ air temperature; $27 \pm 0.3{ }^{\circ} \mathrm{C}$ water temperature; $264 \pm 153 \mathrm{~mm}$ precipitation. Daily averages during the dry season were $20 \pm 1.5^{\circ} \mathrm{C}$ air temperature; $21 \pm 0.5^{\circ} \mathrm{C}$ water temperature; $14 \pm 15 \mathrm{~mm}$ precipitation (Figure 2 and 1 ).

The multiparameter test revealed that variables $\mathrm{pH}$, TSS and TP best explained the composition of the biotic community (AICc $=45.6 ; \mathrm{R} 2=0.80$ ). Moreover, $\mathrm{pH}$ was acidic during the rainy season, water temperature was higher in the rainy summer

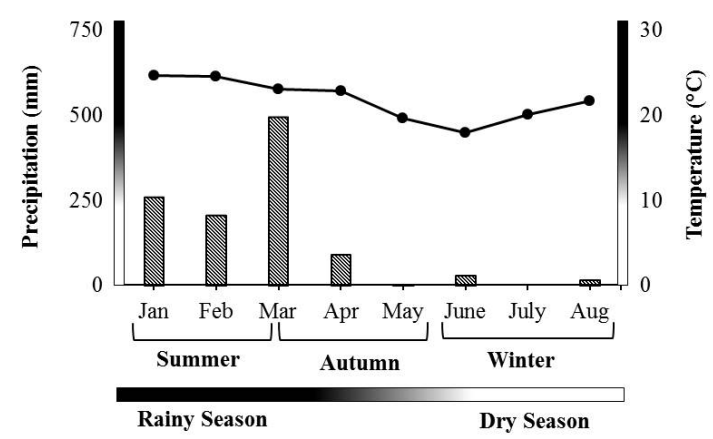

Figure 2. Monthly variation of air temperature (line $-{ }^{\circ} \mathrm{C}$ ) and precipitation (bars - $\mathrm{mm}$ ) during analysis, indicating the rainy and dry seasons. 
and $\mathrm{BOD}_{5}$ was high during the dry winter (May-August). Total phosphorus concentrations in the water column were above $91 \mu \mathrm{g} \mathrm{L}^{-1}$, except at IW2 $\left(52 \mu \mathrm{g} \mathrm{L}^{-1}\right)$ during rainy season and at FP $\left(81 \mu \mathrm{g} \mathrm{L}^{-1}\right)$ and WO $\left(83 \mu \mathrm{g} \mathrm{L}^{-1}\right)$ during the dry season. Total dissolved solids were below $297 \mathrm{mg} \mathrm{L}^{-1}$ and TSS ranged between $9 \mathrm{mg} \mathrm{L}^{-1}$ (WO - rainy season) and $69 \mathrm{mg} \mathrm{L}^{-1}$ (IW2 - dry season). Dissolved oxygen and $\mathrm{BOD}_{5}$ were above $5 \mathrm{mg} \mathrm{L}^{-1}$, during the sampling period. Thermotolerant coliforms were high only at site IW1 during dry season whilst the other sites were similar in both seasons (Table 1).

Although, significant differences in the sediment between the seasons were not reported, they were higher $(\mathrm{p}<0.05)$ between sites, except $\mathrm{Cu}$ ( $\mathrm{p}>0.05$ ). Further, $\mathrm{pH}, \mathrm{Ca}, \mathrm{K}$ and $\mathrm{Mg}$ were higher $(p<0.05)$ in the water inlets than those at the other sites. However, Mn was higher $(\mathrm{p}<0.05)$ in the water outlet in the two seasons. Sediment was acidic and highest nutrient concentration was observed for Ca in both seasons (Table 1).

Only richness of the zooplankton community was high at all sites in the rainy season. Other ecological indexes were high in both seasons, mainly at IW2 where evenness and diversity were high due to Copepoda and Cladocera density (Table 2). Evenness and diversity in the phytoplankton community were high in the water inlets during the rainy season due to abundance of Bacillariophyceae species, featuring almost twice as much as at the other sites. However, indexes at WO were also high during the dry season (Table 2).

The zooplankton community comprised 26 Rotifera species, 3 Copepoda species and 3 Cladocera species. Rotifera was the most abundant group in the zooplankton community in the two seasons, except at IW2 during the dry season when Copepoda was higher, or rather, $52 \%$ of total zooplankton community at this site, due to abundance of Argyrodiaptomus furcatus and Thermocyclops decipiens adults. Eighteen of the recorded species were abundant at any site or during any period. Although no species was abundant at all sites during the sampling period, adult T. decipiens (Copepoda) and Trichocerca similis (Rotifera) were abundant at all sites during the rainy season and Keratella americana and Trichocerca elongata (Rotifera) were abundant at all sites during dry season. A great number of abundant species (13) was observed in the Rotifera group during the

Table 1. Mean and standard deviation of variables measured in the water and sediment during the rainy and dry seasons (IW1 and IW2 = water inlets; FP = deep water site; WO = water outlet).

\begin{tabular}{|c|c|c|c|c|c|c|c|c|}
\hline \multirow{2}{*}{ Variables } & \multicolumn{4}{|c|}{ Rainy season } & \multicolumn{4}{|c|}{ Dry season } \\
\hline & IW1 & IW2 & FP & wo & IW1 & IW2 & FP & wo \\
\hline \multicolumn{9}{|l|}{ Water } \\
\hline TIN (mg L-1) & $1.7 \pm 0.6^{\mathrm{ab}}$ & $1 \pm 0.4^{b}$ & $1.6 \pm 0.8^{\mathrm{ab}}$ & $1.9 \pm 0.2^{\mathrm{ab}}$ & $1.3 \pm 0.5^{\mathrm{ab}}$ & $1.3 \pm 0.6^{a b}$ & $2.4 \pm 0.2^{\mathrm{a}}$ & $1.9 \pm 0.7^{\mathrm{ab}}$ \\
\hline $\mathrm{TP}\left(\mu \mathrm{g} \mathrm{L}^{-1}\right)$ & $138 \pm 22^{a}$ & $120 \pm 47^{a}$ & $129 \pm 20^{a}$ & $117 \pm 30^{\mathrm{a}}$ & $192 \pm 71^{\mathrm{a}}$ & $219 \pm 69^{a}$ & $136 \pm 51^{a}$ & $134 \pm 65^{a}$ \\
\hline $\begin{array}{l}\text { Cond } \\
\left(\mu \mathrm{S} \mathrm{cm}^{-1}\right)\end{array}$ & $108 \pm 5^{a}$ & $91 \pm 13^{b}$ & $107 \pm 3^{a}$ & $106 \pm 3^{a}$ & $110 \pm 3^{a}$ & $102 \pm 4^{\mathrm{ab}}$ & $107 \pm 2^{\mathrm{a}}$ & $105 \pm 3^{a}$ \\
\hline $\begin{array}{l}\text { Temperature } \\
\left({ }^{\circ} \mathrm{C}\right)\end{array}$ & $26 \pm 1^{a}$ & $26 \pm 2^{a}$ & $27 \pm 2^{\mathrm{a}}$ & $27 \pm 2^{\mathrm{a}}$ & $22 \pm 1^{b}$ & $21 \pm 1^{b}$ & $21 \pm 1^{b}$ & $21 \pm 1^{b}$ \\
\hline $\mathrm{DO}\left(\mathrm{mg} \mathrm{L}^{-1}\right)$ & $6 \pm 0.5^{a}$ & $6 \pm 1.4^{a}$ & $7 \pm 2.4^{a}$ & $7 \pm 2.8^{a}$ & $5 \pm 2.6^{a}$ & $5 \pm 1.8^{a}$ & $5 \pm 2.2^{\mathrm{a}}$ & $6 \pm 2.9^{a}$ \\
\hline $\mathrm{pH}$ & $6 \pm 0.3^{a}$ & $6 \pm 0.3^{a}$ & $6 \pm 0.3^{a}$ & $6 \pm 0.3^{a}$ & $7 \pm 0.6^{a}$ & $6 \pm 0.6^{a}$ & $6 \pm 0.7^{a}$ & $7 \pm 0.8^{a}$ \\
\hline TSS $\left(\mathrm{mg} \mathrm{L}^{-1}\right)$ & $27 \pm 9^{a}$ & $33 \pm 15^{a}$ & $18 \pm 3^{a}$ & $15 \pm 1^{a}$ & $27 \pm 13^{a}$ & $29 \pm 27^{a}$ & $23 \pm 9^{a}$ & $19 \pm 12^{a}$ \\
\hline TDS (mg L-1) & $110 \pm 8^{b c}$ & $74 \pm 20^{c}$ & $92 \pm 31^{c}$ & $134 \pm 44^{\mathrm{abc}}$ & $214 \pm 63^{a}$ & $155 \pm 14^{\mathrm{abc}}$ & $204 \pm 70^{\mathrm{ab}}$ & $120 \pm 30^{\mathrm{abc}}$ \\
\hline $\mathrm{BOD}_{5}\left(\mathrm{mg} \mathrm{L}^{-1}\right)$ & $7 \pm 2.9^{\mathrm{bc}}$ & $6 \pm 3.5^{c}$ & $6 \pm 2.2^{c}$ & $5 \pm 1.4^{c}$ & $9 \pm 2.2^{\mathrm{ab}}$ & $9 \pm 1.2^{\mathrm{ab}}$ & $9 \pm 2.2^{\mathrm{ab}}$ & $10 \pm 3.4^{a}$ \\
\hline $\begin{array}{l}\text { TC } \\
\left(\text { MPN } 100 \mathrm{~mL}^{-1} \text { ) }\right.\end{array}$ & $2,250 \pm 903^{b}$ & $372 \pm 280^{\circ}$ & $772 \pm 437^{\mathrm{bc}}$ & $625 \pm 180^{\mathrm{bc}}$ & $4,325 \pm 1,967^{a}$ & $460 \pm 232^{c}$ & $565 \pm 275^{\text {bc }}$ & $160 \pm 36^{c}$ \\
\hline \multicolumn{9}{|l|}{ Sediment } \\
\hline $\mathrm{Cu}\left(\mathrm{mg} \mathrm{Kg}^{-1}\right)$ & $1.1 \pm 0.2^{a}$ & $0.6 \pm 0.2^{\mathrm{a}}$ & $0.8 \pm 0.3^{a}$ & $1.1 \pm 0.1^{\mathrm{a}}$ & $0.7 \pm 0.4^{\mathrm{a}}$ & $0.8 \pm 0.5^{\mathrm{a}}$ & $0.7 \pm 0.2^{\mathrm{a}}$ & $0.9 \pm 0.1^{a}$ \\
\hline $\mathrm{Mg}\left(\mathrm{mg} \mathrm{Kg}^{-1}\right)$ & $347 \pm 111^{\mathrm{ab}}$ & $334 \pm 85^{\mathrm{ab}}$ & $340 \pm 147^{\mathrm{ab}}$ & $140 \pm 12^{b}$ & $480 \pm 115^{a}$ & $322 \pm 102^{\mathrm{ab}}$ & $316 \pm 44^{\mathrm{ab}}$ & $140 \pm 36^{b}$ \\
\hline $\operatorname{Mn}\left(\mathrm{mg} \mathrm{Kg}^{-1}\right)$ & $11 \pm 6^{\mathrm{bc}}$ & $15 \pm 7^{\mathrm{bc}}$ & $3.5 \pm 2^{\mathrm{c}}$ & $49 \pm 10^{\mathrm{a}}$ & $9.5 \pm 3^{b c}$ & $19 \pm 6^{\mathrm{bc}}$ & $2.5 \pm 0.4^{c}$ & $43 \pm 10^{a}$ \\
\hline $\mathrm{P}\left(\mathrm{mg} \mathrm{Kg}^{-1}\right)$ & $112 \pm 35^{\mathrm{ab}}$ & $93 \pm 23^{\mathrm{abc}}$ & $44 \pm 12^{c}$ & $60 \pm 48^{\mathrm{abc}}$ & $117 \pm 25^{a}$ & $117 \pm 13^{\mathrm{a}}$ & $52 \pm 19^{b c}$ & $59 \pm 18^{a b c}$ \\
\hline $\mathrm{K}\left(\mathrm{mg} \mathrm{Kg}^{-1}\right)$ & $90 \pm 16^{\mathrm{ab}}$ & $67 \pm 19^{b c}$ & $69 \pm 22^{\mathrm{abc}}$ & $47 \pm 5^{c}$ & $101 \pm 15^{a}$ & $66 \pm 13^{b c}$ & $70 \pm 5^{\mathrm{abc}}$ & $58 \pm 2^{\mathrm{bc}}$ \\
\hline $\mathrm{Ca}\left(\mathrm{mg} \mathrm{Kg}^{-1}\right)$ & $1,923 \pm 366^{a b}$ & $1,443 \pm 164^{\mathrm{bcd}}$ & $1,252 \pm 491^{\mathrm{cd}}$ & $1,052 \pm 140^{\text {cd }}$ & $2,325 \pm 312^{\mathrm{a}}$ & $1,653 \pm 280^{\text {bc }}$ & $1,182 \pm 148^{\mathrm{cd}}$ & $852 \pm 120^{d}$ \\
\hline $\mathrm{pH}$ & $5.3 \pm 0.3^{\mathrm{ab}}$ & $5.2 \pm 0.2^{\mathrm{ab}}$ & $5.1 \pm 0.1^{\mathrm{b}}$ & $4.8 \pm 0.1^{b}$ & $5.8 \pm 0.4^{\mathrm{a}}$ & $5.3 \pm 0.4^{\mathrm{ab}}$ & $5.1 \pm 0.1^{b}$ & $4.8 \pm 0.2^{b}$ \\
\hline OM (\%) & $1.1 \pm 0.3^{\mathrm{bc}}$ & $1.9 \pm 0.7^{\mathrm{ab}}$ & $1.3 \pm 0.3^{\mathrm{abc}}$ & $1.4 \pm 0^{\mathrm{abc}}$ & $0.7 \pm 0.1^{c}$ & $1.6 \pm 0.3^{a}$ & $1.2 \pm 0.2^{\mathrm{abc}}$ & $1.5 \pm 0.2^{\mathrm{abc}}$ \\
\hline
\end{tabular}

In each row, means followed by the same letter do not significantly differ $(\mathrm{p}<0.05)$. TIN = total inorganic nitrogen; $\mathrm{TP}=$ total phosphorus; Cond = conductivity; $\mathrm{DO}=$ dissolved oxygen; $\mathrm{TSS}=$ total suspended solids; TDS = total dissolved solids; $\mathrm{BOD}_{5}=5$-day biochemical oxygen demand; $\mathrm{TC}=$ thermotolerant coliforms; $\mathrm{OM}=$ organic matter. 
Table 2. Quantitative analyses of phytoplankton and zooplankton communities: density, species richness, evenness, Shannon-Wiener diversity index ( $\left.\mathrm{H}^{\prime}\right)$, total number of taxa and abundant species at sites (IW1 and IW2 = water inlets; FP = deep water site; WO = water outlet) during the rainy and dry seasons.

\begin{tabular}{|c|c|c|c|c|c|c|c|c|}
\hline & \multicolumn{4}{|c|}{ Rainy season } & \multicolumn{4}{|c|}{ Dry season } \\
\hline & IW1 & IW2 & FP & WO & IW1 & IW2 & FP & WO \\
\hline Zooplankton total (Ind. L-1) & 3,885 & 2,390 & 1,200 & 877 & 608 & 1,279 & 1,039 & 688 \\
\hline Cladocera & 389 & 174 & 37 & 60 & 9 & 95 & 18 & 5 \\
\hline Copepoda & 575 & 403 & 374 & 293 & 47 & 667 & 242 & 65 \\
\hline Rotifera & 2,920 & 1,813 & 789 & 524 & 551 & 517 & 779 & 618 \\
\hline Richness & 32 & 29 & 31 & 28 & 30 & 24 & 28 & 21 \\
\hline Evenness & 0.21 & 0.21 & 0.22 & 0.26 & 0.10 & 0.28 & 0.19 & 0.12 \\
\hline Diversity (H') & 0.73 & 0.70 & 0.75 & 0.86 & 0.35 & 0.90 & 0.62 & 0.35 \\
\hline Number of taxa & 34 & 32 & 32 & 31 & 29 & 23 & 29 & 22 \\
\hline Number of abundant species & 10 & 4 & 9 & 11 & 9 & 6 & 12 & 6 \\
\hline Phytoplankton total (Ind. $\mathrm{mL}^{-1}$ ) & 4,322 & 3,155 & 4,900 & 5,105 & 3,135 & 3,850 & 2,880 & 4,505 \\
\hline Bacillariophyceae & 97 & 35 & 20 & 55 & 190 & 230 & 60 & 80 \\
\hline Chlorophyceae & 3,392 & 2,380 & 3,935 & 4,180 & 2,645 & 3,230 & 2,365 & 3,840 \\
\hline Cyanobacteria & 680 & 635 & 845 & 825 & 190 & 280 & 315 & 365 \\
\hline Euglenophyceae & 37 & 40 & 70 & 27 & 15 & 25 & 60 & 185 \\
\hline Zygnematophyceae & 115 & 65 & 30 & 17 & 95 & 85 & 80 & 35 \\
\hline Richness & 43 & 39 & 40 & 36 & 43 & 41 & 38 & 41 \\
\hline Evenness & 0.19 & 0.20 & 0.16 & 0.15 & 0.16 & 0.17 & 0.18 & 0.16 \\
\hline Diversity (H') & 0.70 & 0.72 & 0.59 & 0.55 & 0.61 & 0.62 & 0.66 & 0.58 \\
\hline Number of taxa & 43 & 39 & 38 & 36 & 43 & 42 & 39 & 41 \\
\hline Number of abundant species & 11 & 9 & 12 & 12 & 8 & 16 & 14 & 16 \\
\hline
\end{tabular}

sampling period, with $60-76 \%$ and density between 524-2,921 ind $\mathrm{L}^{-1}$ of total zooplankton during the rainy season and $40-91 \%$ with higher density 517-779 ind $\mathrm{L}^{-1}$ of total zooplankton during the dry season (Figure 3; Table 2). Cladocera had low relative abundance and density, ranging between 37-389 ind $\mathrm{L}^{-1}$, with 3-10\% of total zooplankton during rainy season and 5-95 ind $\mathrm{L}^{-1}$, with $1-7.5 \%$ of total zooplankton during the dry season. Copepoda was abundant during the sampling period with density $293-575$ ind $\mathrm{L}^{-1}$, with $8-52 \%$ of total zooplankton during the rainy season and 47-667 ind $\mathrm{L}^{-1}$ during the dry season and $15-34 \%$ of total zooplankton (Figure 3; Table 2).

The phytoplankton community comprised 48 , with 32 Chlorophyceae taxa, or rather, $76-82 \%$ of total phytoplankton and a higher density 2,380-4,180 ind $\mathrm{L}^{-1}$ during the rainy season. Density reached $2,365-3,890$ ind $\mathrm{L}^{-1}$ during the dry season, with $82-85 \%$ of total phytoplankton. Chlorophyceae was the most abundant group during the sampling period (Figure 3; Table 2). Cyanobacteria was the second most abundant group, with $16-20 \%$ and $6-11 \%$ during rainy and dry seasons, respectively. In the case of, other taxa, Bacillariophyceae revealed high density during the dry season with $60-230$ ind $\mathrm{L}^{-1}$ and $2-6 \%$ of total phytoplankton community during the season. Zygnematophyceae showed high density at IW1,

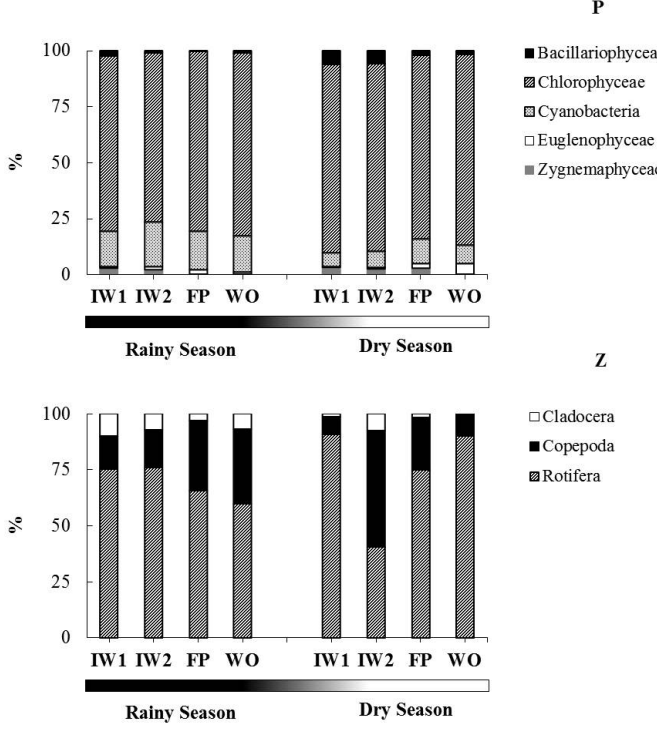

Figure 3. Relative abundance (\%) of zooplankton ( $\mathrm{Z}$ ) and phytoplankton $(\mathrm{P})$ identified recorded during the rainy and dry seasons (IW1 and IW2 = water inlets; FP = deep water site; $\mathrm{WO}=$ water outlet).

with 115 ind $\mathrm{L}^{-1}$ and $3 \%$ of total phytoplankton community during the rainy season. No abundant species were found for this group. Euglenophyceae showed high density at $\mathrm{WO}$, with 185 ind $\mathrm{L}^{-1}$ and $4 \%$ of total phytoplankton community during the dry season (Figure 3; Table 2). Twenty-six 
species were abundant at any site or during any period. Four species of Chlorophycae was abundant at all sites during, both seasons, mainly due to Chlorella vulgaris, Dictyosphaerium pulchellum, Didymocystis fina, and Scenedesmus quadricauda. However, Monoraphidum arcuatum (Chlorophyceae) and Pseudanabaena catenata (Cyanobacteria) were abundant at all sites only during the rainy season, and Monoraphidium caribeum and Tetrastrum komarekii (Chlorophyceae) were abundant at all sites only during the dry season.

During the rainy season, when the continuous water flow is more intense, a high number of plankton taxa were observed at IW1 site, evidencing run-off into the fish pond, with 34 zooplankton taxa and 43 phytoplankton taxa. In the case of phytoplankton, during the dry season a high number of taxa was found (Table 2).

\section{Discussion}

Fluctuation of the planktonic community and environmental variables are strongly affected by intrinsic conditions and continuous water flow, with higher abundance rates during the rainy season, except Bacillariophyceae affected by water $\mathrm{pH}$. Acidic or alkaline water influences aquatic life. Whereas Bacillariophyceae are dominant in an environment with slightly high $\mathrm{pH}$, Chlorophyceae dominate in ponds with lower acidic $\mathrm{pH}$ (Das et al., 2018). Besides $\mathrm{pH}$, Chlorophyceae dominance in fish ponds has been attributed to flexibility in the physiology and behavior of species that tolerate environmental changes better than other species (Ikpi et al., 2013).

A high number of plankton taxa, high contents of several physicochemical parameters, high number of thermotolerant coliforms and slight sediment nutrient concentrations were observed in the water inlets. Biotic and abiotic materials proceeding from the other ponds may be transformed into available feed to the plankton community with high population density. However, high levels of total inorganic nitrogen, total phosphorus $\mathrm{BOD}_{5}$, TDS and thermotolerant coliforms (water inlets) were reported during the dry season, with approximately $30 \%$ and $10 \%$ decrease in the density of the zooplankton and phytoplankton communities, respectively, and with dissolved oxygen less than $3.5 \mathrm{mg} \mathrm{L}^{-1}$. Actually, it is very difficult to predict which is the main factor that affect the biotic water conditions within a fish pond with constant entrance of allochthonous material.
Since it depends on the concentration of TDS increase, the electrical conductivity that affects phytoplankton diversity is inversely correlated with these parameters (Pal et al., 2018). Low phytoplankton diversity observed in current study may be related with high conductivity and TDS found in the fish pond.

Density decrease of Cyanobacteria during the dry season may be perceived in the drastic reduction of Cladocera. According to Panosso et al. (2003), species of Cladocera employ filaments of Cyanobacteria as food source. In current study, abundance of Cladocera has been related to high Cyanobacteria density and low concentration of organic matter $(<2 \%)$ and TSS $\left(<40 \mathrm{mg} \mathrm{L}^{-1}\right)$ during the sampling period. Moreover, a low percentage of Cyanobacteria in the fish pond suggests insufficient nutrient availability (mainly $\mathrm{P}$ ) to trigger the blooming of Cyanobacteria.

When Copepoda was abundant at the different sites, particularly through the occurrence of Thermocyclops decipiens, a decrease in the Rotifera population was reported. The above Copepoda species adapts to the conditions of environments rich in nutrients and to water with relatively high electrical conductivity (Almeida \& Fernandes, 2013). Since,, electrical conductivity of the fish pond remained above $80 \mu \mathrm{S} \mathrm{cm}^{-1}$, in current analysis, $T$. decipiens was enhanced at all sites, with the exception of WO during the dry season.

Sipaúba-Tavares et al. (2017) analyzed the same fish pond two years before, or rather, during the mono-and multi-species macrophyte invasion, and verified that zooplankton density was more than twice as much as that given in current study. It became clear that invasions by aquatic plants and their posterior physical removal significantly influenced the population, since plankton organisms are highly sensitive to environmental changes. However, in current study, Rotifera was dominant in both seasons, as reported. The group was capable of adapting itself fast to environmental changes (r-strategists), characteristics of environments with high nutrient and organic matter levels. Rotifera is dominant in environments with high nutrient inputs. Arruda et al. (2017) observed that a high density of Rotifera has often been registered with a great density of Cyanobacteria. This fact has been observed in current study during the rainy season.

The plankton community in the studied pond is characteristic of small water bodies with dominance of Rotifera in the zooplankton community. In the case of phytoplankton 
community, Chlorophyceae, Cyanobacteria and Bacillariophyceae were dominant, followed by Zygnematophyceae and Euglenophyceae. Zygnematophyceae and Cyanobacteria have been often in eutrophic waters. Euglenophyceae is common and abundant in natural shallow bodies. Differentiation between Bacillariophyceae, Chlorophyceae and other microalga groups is closely allied to the availability of their preferred physicochemical parameters, particularly ponds (Zebek \& Szymanska, 2017). The water that drains in the fish pond with numerous macro-and micro-nutrients, maintained its favorable conditions for the plankton community.

According to Chi et al. (2010), the nearneutral $\mathrm{pH}$ indicated high $\mathrm{Ca}$ concentrations in the soil. The sediment in the fish pond was acidic, lower than 6.2 , but $\mathrm{Ca}$ concentration was high, over $721 \mathrm{mg} \mathrm{L}^{-1}$. Phosphorus distribution and accumulation in the sediment are related to the loading of allochthonous and autochthonous sources and sediment properties composition, particle size distribution, hydrology and $\mathrm{pH}$ (Shao et al., 2014). Phosphorus concentration was high in water inlets due to the contribution of allochthonous materials from other fish ponds, while Mn was high at the water outlet.

There are many extrinsic and intrinsic factors in the fish pond associated with limnological variables directly affecting its characteristics. Allochthonous material to the fish pond during the two seasons mainly contributes to nutrients, thermotolerant coliforms, $\mathrm{Ca}, \mathrm{Fe}, \mathrm{Cu}, \mathrm{Mg}$ and $\mathrm{P}$ which influence the plankton community and enhance high Cyanobacteria density in the rainy season. The fish pond under analysis remained without any feed for one year and with low fish density. This fact did not affect the high decrease in nutrient concentrations and biotic communities. It should be underscored that these conditions remained stable throughout the monitoring period due to the serial disposition of the fishponds, even with the continuous water flow during the dry and rainy seasons. However, the continuous use of fish ponds with high densities is required in the production system of aquatic organisms. Consequently, the constant addition of feed is relevant so that production would not be jeopardized. The direct use of water from this fish pond to supply other ponds and the shrimp farming sector should be reassessed due to high concentrations of TIN, $\mathrm{BOD}_{5}$, TDS, thermotolerant coliforms and Cyanobacteria. The above may have liabilities in the sites to be supplied. Management protocol in places with continuous water flow according to the region may be an important tool to optimize and to avoid risks in fish production.

\section{Acknowledgements}

The authors would like to thank the Brazilian Council for Scientific and Technological Development $(\mathrm{CNPq})$ and the Research Foundation of the State of São Paulo (FAPESP) for the award of scholarship to the fourth author (13/05423-7) and for funding (12/09884-4).

\section{References}

ALMEIDA, S.Z. and FERNANDES, V.O. Effects of intensive fish-farming and domestic waste water on the periphytic algal community in a tropical coastal lagoon (Juara, Brazil). Acta Scientiarum. Biological Sciences, 2013, 35(3), 335-342. http://dx.doi. org/10.4025/actascibiolsci.v35i3.17094.

AMERICAN PUBLIC HEALTH ASSOCIATION - APHA. Standard methods for the examination of water and wastewater. 19th ed. Washington: APHA, 1995. $1100 \mathrm{p}$.

ANDERSON, M.J., GORLEY, R.N. and CLARKE, K.R. PERMANOVA + for PRIMER: guide to software and statistical methods. Plymouth: PRIMER-E, 2008.

ARRUDA, G.A., DINIZ, L.P., ALMEIDA, V.L.S., NEUMANN-LEITÁO, S. and MELO JÚNIOR, M. Rotifer community structure in fish-farming systems associated with a Neotropical semiarid reservoir in north-eastern Brazil. Aquaculture Research, 2017, 48(1), 4910-4922. http://dx.doi. org/10.1111/are.13310.

BALKIĆ, A.G., TERNJEJ, I. and ŠPOLJAR, M. Hydrology driven changes in the rotifer trophic structure and implications for food web interactions. Ecohydrology, 2018, 11(1), e1917. http://dx.doi. org/10.1002/eco.1917.

BOYD, C.E. and TUCKER, C.S. Water quality and pond soil analyses for aquaculture. Auburn: Alabama Agricultural Experiment Station, 1992, 183 p.

BURNHAM, K.P. and ANDERSON, D.R. Model selection and multi-model inference: a practical information - theoretic approach. 2nd ed. New York: Springer-Verlag, 2002. $488 \mathrm{p}$.

CHI, G., CHEN, X., SHI, Y. and ZHENG, T. Forms and profile distribution of soil $\mathrm{Fe}$ in the Sanjinang plain of northeast China as affected by land uses. Journal of Soils and Sediments, 2010, 10(4), 787-795. http://dx.doi.org/10.1007/s11368-009-0140-7.

CLARKE, K.R. and WARWICK, R.W. Change in marine communities: an approach to statistical analysis 
and interpretation. Plymouth: Plymouth Marine Laboratory, 1994, $144 \mathrm{p}$.

DAS, D., PATHAK, A. and SUDIN, P. Diversity of phytoplankton in some domestic wastewater-fed urban fish pond ecosystem of the Chota Nagpur Plateau in Bankura, India. Applied Water Science, 2018, 8(84), 1-13.

FONSECA, B.M. and BICUDO, C.E.M. How important can the presence/absence of macrophytes be in determining phytoplankton strategies in two tropical shallow reservoirs with different trophics status? Journal of Plankton Research, 2010, 32(1), 31-46. http://dx.doi.org/10.1093/plankt/fbp107.

GOLTERMAN, H.L., CLYMO, R.S. and OHNSTAD, M.A.M. Methods for physical and chemical analysis of fresh water. Oxford: Blackwell Scientific Publication, 1978, 214 p.

IKPI, G.U., OFFEM, B.O. and OKEY, I.B. Plankton distribution and diversity in tropical earthen fish ponds. Environment and Natural Resources Research, 2013, 3(3), 45-51. http://dx.doi.org/10.5539/enrr. $\mathrm{v} 3 \mathrm{n} 3 \mathrm{p} 45$.

KOPP, R., ŘEZNÍČKOVÁ, P., HADAŠOVÁ, L., PETREK, R. and BRABEC, T. Water quality and phytoplankton communities in newly created fish ponds. Acta Universitatis Agriculturae et Silviculturae Mendelianae Brunensis, 2016, 64(1), 71-80. http:// dx.doi.org/10.11118/actaun201664010071.

KOROLEFF, F. Determination of nutrients. In: E. GRASHOF and E. KREMLING, orgs. Methods of seawater analysis. German: Verlag Chemie Wenhein, 1976, 181 p.

LOBO, E. and LEIGHTON, G. Estructuras comunitarias de las fitocenosis planctonicas de los sistemas de desembocaduras de ríos y esteros de la zona central de Chile. Revista de Biología Marina y Oceanografía, 1986, 22(1), 1-29.

LUND, J.W.G., KIPLING, C. and LE CREN, E.D. The inverted microscope method of estimating algal numbers and the statistical basis of estimations by counting. Hydrobiologia, 1958, 11(2), 143-170. http://dx.doi.org/10.1007/BF00007865.

PAL, S., CHAKRABORTY, S., DATTA, S. and MUKHOPADHYAY, S.K. Spatio-temporal variations in total carbon in contaminated surface waters at east Kolkata wetland ecosystem, a Ramar site. Ecological Engineering, 2018, 110(1), 146-157. http://dx.doi.org/10.1016/j.ecoleng.2017.11.009.

PANOSSO, R., CARLSSON, P., KOZLOWSKYSUZUKI, B., AZEVEDO, S.M.F.O. and GRANÉLI, E. Effect of grazing by a neotropical copepod, Notodiaptomus, on a natural cyanobacterial assemblage and on toxic and non-toxic cyanobacterial strains. Journal of Plankton Research, 2003, 25(9), 1169. 1175. http://dx.doi.org/10.1093/plankt/25.9.1169.

PIELOU, E.C. Ecological diversity. New York: John Wiley, 1975, $165 \mathrm{p}$.

RAIJ, B.V., ANDRADE, J.C., CANTARELLE, H. and QUAGGIO, J.A. Chemical analysis for evaluation of fertility of tropical soils. Campinas: Instituto Agronômico, 2001

SHAO, X., LIANG, X., WU, M., GU, B., LI, W., SHENG, X. and WANG, S. Influence of sediment properties and macrophytes on phosphorous speciation in the intertidal marsh. Environmental Science and Pollution Research International, 2014, 21(17), 10432-10441. http://dx.doi.org/10.1007/ s11356-014-2957-x. PMid:24788863.

SIPAÚBA-TAVARES, L.H., ANATRIELLO, C.B., MILSTEIN, A., MILLAN, R.N. and SCARDOELITRUZZI, B. Macrophyte - environment relationships during a monospecific and a multispecific massive invasion in a fish pond. Tropical Plant Research, 2017, 4(3), 277-283. http://dx.doi.org/10.22271/ tpr.2017.v4.i3.063.

SIPAÚBA-TAVARES, L.H.S., MILLAN, R.N. and AMARAL, A.A. Influence of management on plankton community of fish pond during dry and rainy seasons. Acta Limnologica Brasiliensia, 2010, 22(1), 70-79. http://dx.doi.org/10.4322/ actalb.02201009.

ZEBEK, B. and SZYMANSKA, U. Abundance, biomass and community structure of pond phytoplankton related to the catchment characteristics. Knowledge and Management of Aquatic Ecosystems, 2017, 418(45), 1-9.

Received: 14 May 2018 Accepted: 08 March 2019 